\title{
The impact of cluster networking on business performance of Croatian wood cluster members
}

\author{
Ivana Rašić Bakarić \\ The Institute of Economics, Zagreb, Zagreb, Croatia \\ irasic@eizg.hr
}

\begin{abstract}
This paper investigates the link between cluster membership and performance of clustered companies. The object of the study is the Croatian Wood Cluster (CWC). The paper presents the results of a survey of 34 members of the Croatian Wood Cluster operating in wood and furniture industries. The survey was conducted in order to identify and analyse perceptions and attitudes of CWC members towards CWC objectives, activities and performance; the cooperation strength among cluster members and that with the players outside the cluster; the effects of clustering on the operational performance of the clustered SMEs; business and economic setting in Croatia, barriers for the work of the CWC and the relevancy of government policy measures. The empirical results indicate that the economic performance of the clustered companies is significantly predicted by the cooperation with public institutions, financial institutions and professional associations (such as the Agency for Investments and Competitiveness) provided by the CWC and by the access to cluster resources such as horizontal cooperation, fairs, exhibitions etc. Additionally, an access to credit, customers and competitors shows a significant positive effect on finance-based performance of the clustered companies. On the other hand, cooperation among cluster members and cooperation with scientific, high education and research institutions show no significant relationship with the company performance.
\end{abstract}

Keywords: cooperation, economic performance, industrial clusters, wood and furniture industry.

JEL classification: L16, L25, L68, L73.

DOI: $10.1515 /$ crebss-2017-0008

Received: October 05, 2017

Accepted: December 25, 2017

Acknowledgement: This work has been fully supported by SmartElZ project, which has received funding from the European Union's Horizon 2020. 


\section{Introduction}

Recently, the concept of clusters has attracted much attention to the extent that policy-makers, practitioners and academics alike are increasingly invoking it. Clusters are viewed as the key drivers of competitiveness and innovation and therefore, of growth and jobs. According to literature, industrial clusters (Giuliani, 2005) have a great potential to improve the competitiveness of enterprises, create jobs, increase productivity, innovation, enable new business formations, while reducing costs (Giuliani, Ravelotti, Pietrobello, 2005, Morrison, Rabellotti, Zirulka, 2013, Pyke, Sengenberger, 1992). Policy makers have become more and more interested to obtain information about whether a cluster is successful and whether it has reached defined goals or not. This should help them to identify whether interventions, incentives, promotions and financing have been beneficial for the desired purposes and whether they have been used properly.

Currently, there are two types of clusters in Croatia, the first being industrial/business clusters, and the other which consists of 13 competitiveness clusters. Competitiveness clusters were initiated in 2013 and according to Smart Specialization Strategy (Croatian S3 document) they are defined as "non-profit organizations operating within sectors of strategic importance for the development, linking private, scientific-research and public institutions (triple helix)". Unlike competitiveness clusters that have been established exclusively by the state, industrial/business clusters have been commonly established at the members' initiative (mostly in the form of industry or employers' associations). According to the data from the Croatian Chamber of Economy, there are 65 business clusters in Croatia, which bring together around 460 companies (Croatian Chamber of Economy, 2016).

This paper presents the main results of the survey conducted among the members of the Croatian Wood Cluster $(n=34)$ related to the perceptions and attitudes of the CWC members towards the CWC objectives, activities and performance; the strength of cooperation among cluster members and that with players outside the cluster; the effects of clustering on operational performance of the clustered SMEs; business and economic setting in Croatia, barriers for the work of the CWC and the relevancy of government policy measures.

The Croatian Wood Cluster was chosen, partly, based on the statements made by authors who consider it as one of the most important clusters in the Croatian wood and furniture industry and in the country (Kersan Škabić, 2014). The Cluster was established in 2002 as the Centre for the Promotion and Development of the Wood industry, then it was re-registered in 2010 as a private limited company, Drvni centar d.o.o., since 2013, it has been operating as a professional association with 2 employees. The CWC is a group of connected companies in the field of forestry, wood processing, furniture production and similar activities (registered for the activities in C16 and C31 according to the statistical classification of economic activities in the European Community revision 2 (NACE Rev. 2). The main goal of the CWC is to improve sustainable competitiveness of the wood processing sector, especially regarding the encouragement and promotion of inter-sectoral and trans-sectoral cooperation. The cluster has 61 members with 5,300 employees, accounting for $22.3 \%$ of the total wood-based industry employment. The Cluster is "focused on applying innovations and strengthening the impacts of different types of education but it also has other functions that are of interest to the cluster members" (Hrvatski drvni klaster, 2014). Through these multiple activities, the Cluster integrates all sectors to work together and to cooperate and it strengthens joint operations. 
There have been numerous research studies examining the link between various factors of industrial clustering and company performance, providing a common proposition concerning positive effects of industrial clustering on performance enhancement of the clustered companies (Baptista, Swann, 1998; Krugman, 1991; Porter, 1998a, b). The aim of this study is to expand current knowledge by examining relationships between industrial clustering and cooperation and operational performance of the clustered companies within the context of the Croatian Wood Cluster. The paper answers the following two research questions (RQ):

First: Do industrial clustering impact performance of the clustered companies?

Second: What aspects of networking and cooperation provided by the cluster are associated with SMEs' business performance?

In line with the two research questions, the hypotheses were formulated as follows:

$\mathrm{H1}$ : Cooperation of the cluster with public (especially with the Agency for Investments and Competitiveness) and financial institutions and access to cluster resources are positively and significantly associated with finance-based performance of the clustered companies.

$\mathrm{H} 2$ : Cooperation of the cluster with scientific, high education and research institutions is positively and significantly associated with finance-based performance of the clustered companies.

H3: Access to cluster resources such as credit, customers and competitors is positively and significantly associated with finance-based performance of the clustered companies.

H4: Cooperation within the cluster is positively and significantly associated with finance-based performance of the clustered companies.

The findings aim to contribute towards the understanding of the effects of industrial clustering and cooperation on operational performance of the clustered companies. They can also help SMEs management obtain more insight into industrial clustering as an instrument for developing operational performance of the clustered SMEs. The findings contribute to the literature by providing a better understanding of perceptions and attitudes of the clustered companies towards the CWC objectives, activities and performance, the strength of cooperation among cluster members and with the players outside the cluster; the effects of clustering on companies' operational performance; business and economic setting in Croatia, barriers for the work of the CWC and the relevancy of government policy measures. Additionally, the findings can be useful for deriving policy recommendations for cluster policy in Croatia. The paper is organized as follows: Section 2 presents a review of relevant literature. Section 3 featuring a description of recent developments in the Croatian wood and furniture industry follows this. Methodology employed to carry out the empirical work is presented in Section 4, while Section 5 comprises the results and discussions. Finally, the conclusions of the study are presented in Section 6.

\section{Literature review}

During recent years, researchers have awakened, and an increasing number of studies on the subject of industrial clusters have emerged. Researches on the topic of industrial clusters have been stimulated by successful performance of industrial districts in the developed countries, especially in Italy.

Various cluster theories stem from earlier work by Marshall (1920) on industrial districts, by Isard (1956) on industrial complex, by Perroux (1950) on growth poles 
and by Lundvall and Johnson (1994) on the innovative milieu perspective. Marshall in his The Principles of Economics (Marshall, 1890) first used the term industrial districts. Marshall defines localized industries as an industry concentrated in certain localities and specifies the main determinants of localization of industries. According to Marshall, the main determinants are related to physical conditions (climate and soil) and demand conditions (such as higher proportion of rich people in a specific region (Marshall, 1920). Mainstream cluster researchers rely on some variation of Porter's definition, Porter defines cluster as a group of interconnected companies and institutions in a specific geographical area, connected by complementarities and commonalities. Literature lists several more definitions of the concept of the cluster. According to Altenburg and MeyerStamer (1999), industrial clusters are defined as a large agglomeration of companies that are located in a specific area and characterized by a specific profile of specialization. Crouch and Farrell (2001) provide more general concept of "cluster" suggesting that companies active in similar activities are usually placed in close proximity to one another. Meanwhile, Simmie and Sennett (1999) give another definition by stating an innovative cluster as a large number of interconnected companies that operate under the same market conditions and which characterizes the intensive mutual cooperation, mainly through the supply chain. On the other hand, Morosini (2004) refers to an industrial cluster as a socioeconomic entity made up of the social community of people, and the population of the economic agents who are located close to each other. According to OECD (1999) definition, clusters comprise the strongly interdependent companies; universities, research institutes and institutions engaged in research and development activities; consultants, brokers and customers.

Most researches on clusters have considered agglomeration externalities as the key clustering driver. Agglomeration externalities arise due to non-market interactions (paraphrasing, Fujita, Thisse, 2002). Forms of externalities arising from industry specialisation stem from traditional economic theory. Knowledge spillovers may occur between companies within the same industry and be encouraged by local concentrations of a particular industry (the Marshall-ArrowRomer (MAR) type localization or 'specialization' externalities) (Marshall, 1890, Arrow, 1962, Romer, 1986). According to the MAR type externalities, knowledge spillovers in specialized geographically concentrated industries stimulate growth.

Recent studies have investigated how industrial clusters affects performance, providing empirical evidence regarding positive effects of clusters on company performance. According to Altenburg and Meyer-Stamer (1999), industrial clustering enables companies, especially SMEs, to develop more easily. Based on the research of industrial clusters in Spain and Italy, Hervas-Oliverand and Albors Garrigos (1997) found that the existence of interconnected industries and supporting institutions in an industrial cluster has a positive impact on productivity and financially based performance of the clustered companies. Hendry and Brown (2006) showed that there is a positive relationship between local network and financially based performance of the clustered companies in UK. This is additionally confirmed by the study of Chiu (2009) (the case of clustered Taiwan companies), who found a positive relationship between the local network and business and innovation performance of the connected companies. Bertolini and Giovannetti (2006) found that geographic clustering of companies encourage the presence of a local network, which enables the clustered companies to enhance their innovation activities. Similarly, Kesidou and Szirmai (2012) found out 
that the knowledge spill-over in an industrial cluster improves innovation performance of the clustered companies, while Muscio (2006) demonstrated that the existence of connected industries in an industrial cluster has a positive effect on improving the ability of innovation of products.

Wood sector is one of the most important branches of the Croatian economy. This sector falls under the manufacturing, which largely contributes, to the national economy. Forests cover nearly a half $(47.0 \%)$ of the Croatian territory, the total forest area amounts to 2.7 million hectares and the total growing wood stock reached 398 million cubic meters (Hrvatske šume, 2017). Comparative advantage of the Croatian wood industry relates to the presence of abundant high-quality raw materials, long tradition and high-quality human resources. However, R\&D, product innovation and design are other intangible crucial drivers of the sector development and the key drivers of competitiveness). In accordance with the definition provided by the Croatian wood cluster, the wood sector consists of two sectors: wood and of products of wood and cork manufacturing (C16) and furniture manufacturing (C13). Croatian wood sector provides 25,235 jobs (15,776 in wood and wood processing industry and 9,459 in furniture industry) directly accounting for $10.2 \%$ of the total Croatian employment in the manufacturing industry. According to Eurostat Structural Business Statistics, the number of employees is defined as those persons who work for an employer based on work contract (Eurostat, 2014). Furniture and wood industries' share of GDP reached 0.9 percent in 2015, while the share of manufacturing GDP was 10.0 percent. Wood, wood processing and furniture industry in Croatia includes 2,617 companies (Croatian Bureau of Statistics, 2016), and they represent $13.3 \%$ of manufacturing enterprises which is slightly below the EU average of 13.9. Thereby, 1,680 companies are operating in wood and wood processing industry, while 937 companies are engaged in furniture manufacturing. Companies are mostly small and medium enterprises and there are only 7 large companies (with more than 250 employees and either an annual turnover at the level above the EUR 50 million or a balance sheet total of over EUR 43 million - according to the current SME definition by European Commission). The average number of person employed per company in wood based sector is 9.3 (9.0 in C16 and 9.7 in C31) in Croatia, compared to around 5.8 in EU28 (4.8 in C16 and 7.1 in C31) (Eurostat SBS, 2014). In terms of the EU, Croatian wood and the furniture industry makes up only a small part of European industry, and accounted for $0.5 \%$ of the EU wood and furniture production and $1.5 \%$ of the EU28 employment in wood based industry in 2014 (Eurostat, 2014). The Croatian wood and furniture industry is strongly export oriented (Figure 1). According to Croatian statistics, in 2016 wood and furniture products trade balance was positive and reached EUR 397.8 million, as opposed to total goods Croatian balance which was negative and amounted to EUR 7.4 billion (Croatian Bureau of Statistics, 2016). 


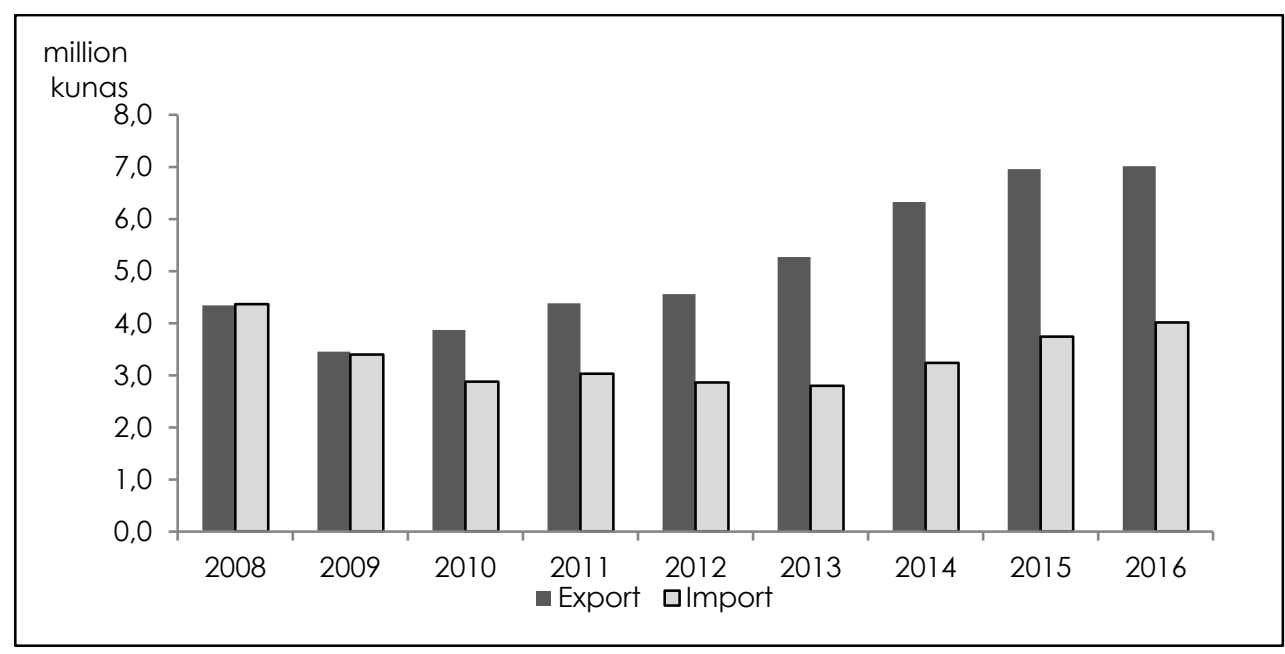

Figure 1 Trade balance of wood-based industries

Source: author's calculation based on Croatian Bureau of Statistics data, 2016.

The main export and import markets of the Croatian wood-based industry are Italy, Germany, Slovenia and Austria (Kersan-Škabić, 2014). However, the structure of export products is rather unfavourable; traditionally, the export of the Croatian wood sector is concentrated on raw wood material and semi-finished goods that generate the lowest added value (sawn timber and elements). According to the Croatian statistics, raw wood material (sawn timber and elements) accounts for $63 \%$ of wooden export, while $37 \%$ of total wood export makes the furniture export (Croatian Bureau of Statistics, 2016). On the other hand, the furniture import accounts for $52 \%$ of total wood import, while wood and wood products import accounts for $48 \%$ of total wood import (Croatian Bureau of Statistics, 2016). The financial crisis had a negative impact on Croatian economy, resulting in decrease of domestic and foreign demand in 2009, which in turn resulted in the decline of export and import in wood industry. Croatian wood industry should enhance its competitiveness by supporting the activities related to research, development of technology, and applying and commercialisation of innovation.

\section{The performance of the Croatian wood based industries in the last decade}

Trends in the Croatian manufacturing industry are negative. The total number of manufacturing companies had been reduced by 22.2\% between 2009 and 2015 . Furthermore, the biggest decreases were recorded in wood and wood processing industry, a fall by $28.8 \%$, while furniture industry recorded increase of $14.5 \%$. In the period of 2009-2015, manufacturing employment in Croatia fell by $17.5 \%$. At the same time, the largest losses within the wood-based industry were recorded in furniture manufacturing, by $25.6 \%$, while wood and wood processing industry employment fell by $12.3 \%$. However, if newer data are analysed, the beginning of recovery in the Croatian wood-based industry can be seen. There is a slight growth in gross value added and production (Figures 2 and 3). In addition, the sector has achieved a significant increase in export. In 2009, because of global crisis domestic and foreign demand decreased which led to the decline of export and import in wood industry. However, following this decline the value of exports of goods began to increase again until 2016 (Figure 1). Particularly good news is the growth of furniture export between 2009 and 2015, which has grown by 80.7 percent between 2009 and 2016. Export in section 16 has increased by $119 \%$. 
Imports for sections 16 and 31 have increased by $29.8 \%$ and $9.02 \%$, respectively (Figure 1).

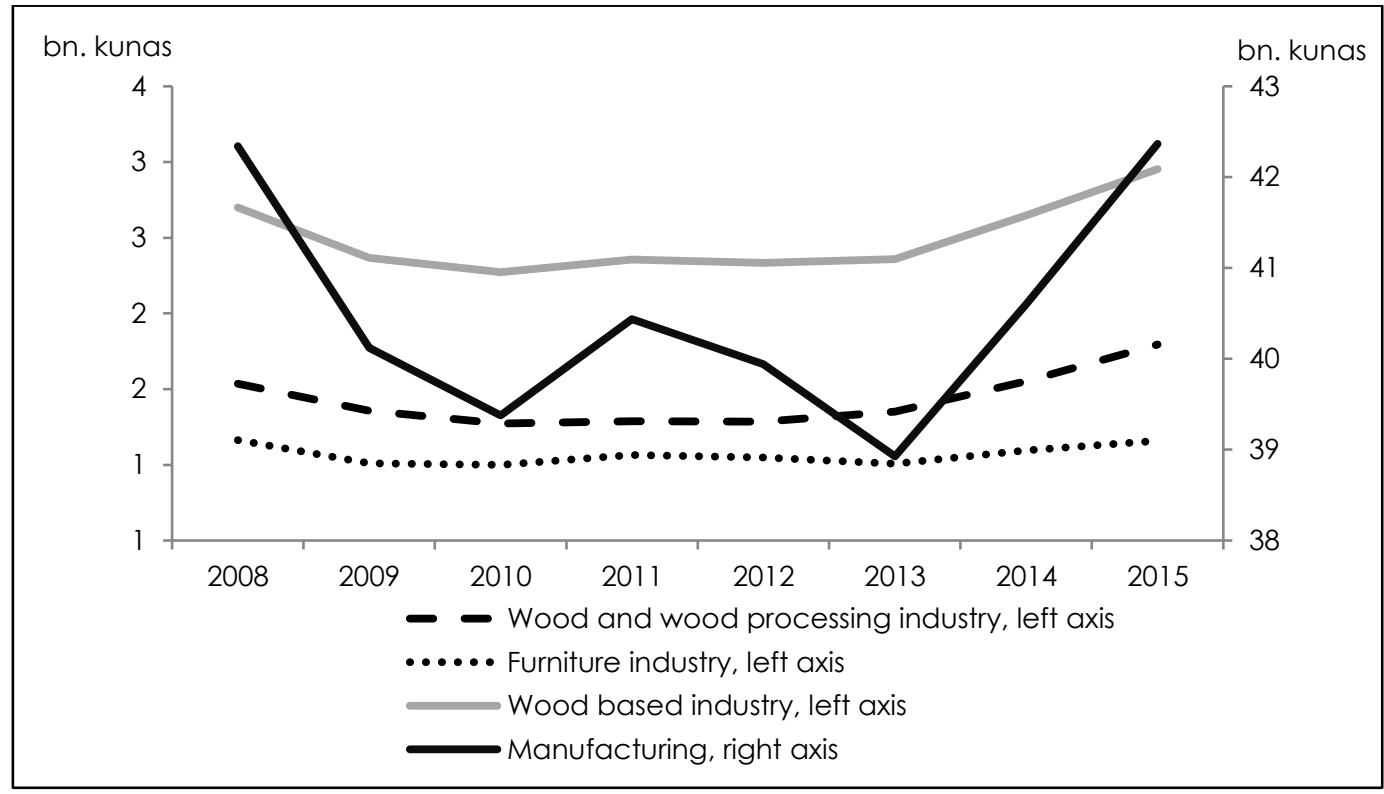

Figure 2 GVA, current prices, billion Kuna, 2008-2015

Source: author's calculation based on Croatian Bureau of Statistics data, 2016.

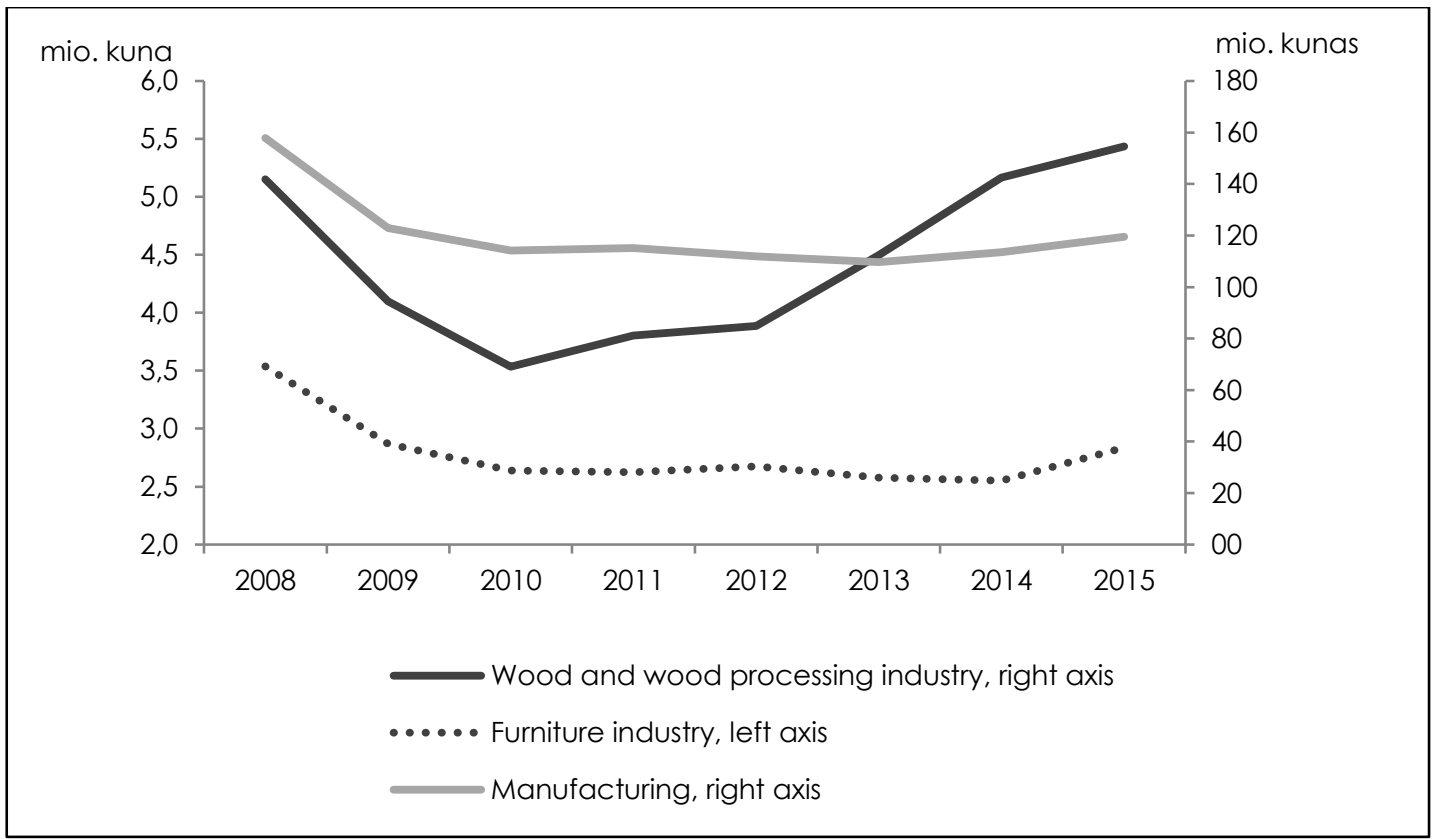

Figure 3 Production values, million Kuna, 2008-2015

Source: author's calculation based on Croatian Bureau of Statistics data, 2016.

Since the Croatian wood industry has recognised the need for the formation of business clusters, there are several of them and they are mostly regional industrial clusters: Wood Cluster of North-western Croatia Cooperative (Drvni klaster sjeverozapadne Hrvatske); "Slavonian oak" (Slavonski hrast); A massive furniture manufacturer cluster (Udruga Klaster proizvođača masivnog namještaja); Cluster "Hrvatski interijeri d.o.o.; VIRIDIS - Wood Cluster Virovitica (Drvni klaster Virovitičkopodravske županije), Association of Cluster of Wood Processing Companies VALIS EU (Udruga Klaster drvoprerađivača VALIS EU). The Croatian Wood Cluster (61 
members) is not only the most important among wood clusters, it is one of the most important cluster business clusters in Croatia (Kersan-Škabić, 2014). Clusters should help members in segments where they are not strong enough or where they are running out of ideas, knowledge, and in the end, and financial resources (Kersan-Škabić, Afrić Rakitovac, 2011 ).

\section{Research Methodology \\ Data collection and methodology}

Data used in this study was obtained from a survey, which was carried out among the members of the Croatian Wood Cluster. Population (according to the CWC database) included 61 active members of the Croatian Wood Cluster, mainly small and medium size companies.

The survey was designed based on literature review and interviews with experts (presidents of the CWC and its members). Pre-testing included five respondents. The survey was conducted online during the months of June and July 2017. Neither the issue of "speeding" (i.e., giving answers very quickly) nor the issue of satisfying was not examined. Respondents' target group included professionals in managerial positions. Computer-Assisted Web Interviewing Method (Google forms) was used to collect data during the period of June-July 2017. Data was analysed by using descriptive statistics, reliability analysis, factor analysis and regression analysis. The survey data was analysed using SPSS 17.0 statistical application software. The results of factor analysis were used as input variables in regression. The survey was conducted in order to identify and analyse the perceptions and attitudes of members of the Croatian Wood Cluster (CWC) regarding the performance of the $\mathrm{CWC}$; the strength of cooperation among cluster members and with the players outside the cluster; the effects of clustering on operational performance of the manufacturing SMEs (members of clusters); business and economic setting in Croatia, barriers for the work of the CWC and the relevancy of government policy measures. This survey was conducted in the framework of SmartEIZ Project H2O Project.

Table 1 Reliability analysis

\begin{tabular}{|l|r|r|}
\hline \multicolumn{1}{|c|}{ Scale } & $\begin{array}{c}\text { Cronbach } \\
\text { alpha }\end{array}$ & $\begin{array}{c}\text { No. of } \\
\text { statements }\end{array}$ \\
\hline Cooperation within the cluster scale & 0.832 & 7 \\
Strength of cooperation within the cluster scale & 0.945 & 9 \\
Access to resources as a source of competitiveness scale & 0.961 & 14 \\
Business and economic settings in Croatia scale & 0.956 & 8 \\
Effects of clusters membership scale & 0.922 & 17 \\
Cluster effects in the last 3 years scale & 0.972 & 14 \\
Main barriers for the work of cluster & 0.845 & 7 \\
Recommendations for improving the performance of the & 0.961 & 11 \\
cluster & & 17 \\
Assessing the government policy measures for cluster & 0.967 & \\
development & & \\
\hline
\end{tabular}

Source: author's calculation.

The research tool was organized into two parts. In the first part, the respondents characterized the company, and in the second part they responded to 104 closed questions on a Likert scale of 1-5 (mostly in the form disagree completely to agree completely). The return rate was about $55.74 \%$ as 34 questionnaires suitable 
for assessment were obtained. The reliability of the scales was tested before data analysis and was measured by Cronbach Alpha. Since alpha values for all 10 scales were over 0.80, it can be concluded that scales were highly reliable (Cronbach, 1951).

\section{Sample profile}

The largest percentage of the respondents were managing directors $(39.4 \%)$, followed by senior managers, such as heads of business units $(27 \%), 18 \%$ of the respondents were presidents or members of supervisory or management boards, while only $6.1 \%$ of respondents were C-level executives such as chief executive officers (CEOS) (Figure 4). One third of companies in the sample were located in Primorje - Gorski Kotar County (which is not surprising since this county is a mountainous part of the Croatian mainland and it has a long tradition of forestry and wood processing industry), followed by Zagreb County and Sisak - Moslavina County. It should be noted that Primorje- Gorski kotar County is among the most economically developed counties in Croatia, along with Zagreb and Istria (Figure $5)$.

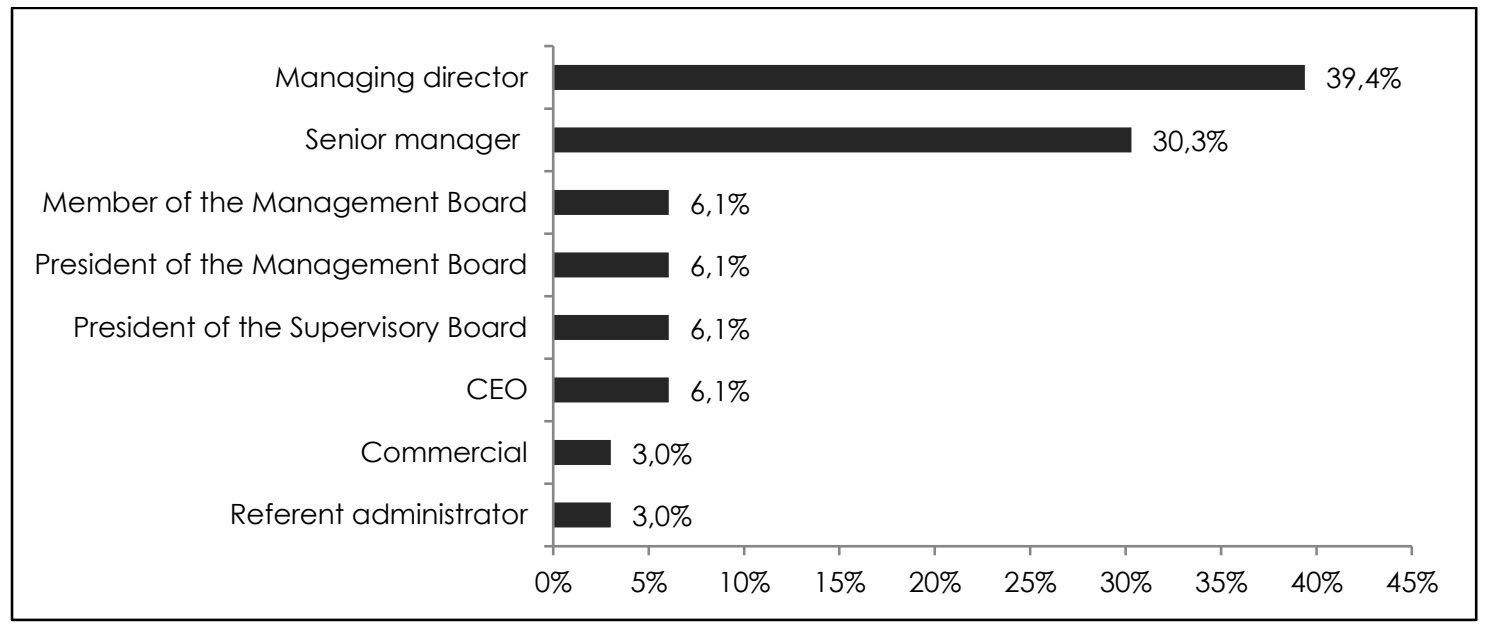

Figure 4 Respondents' profile

Source: author's calculation.

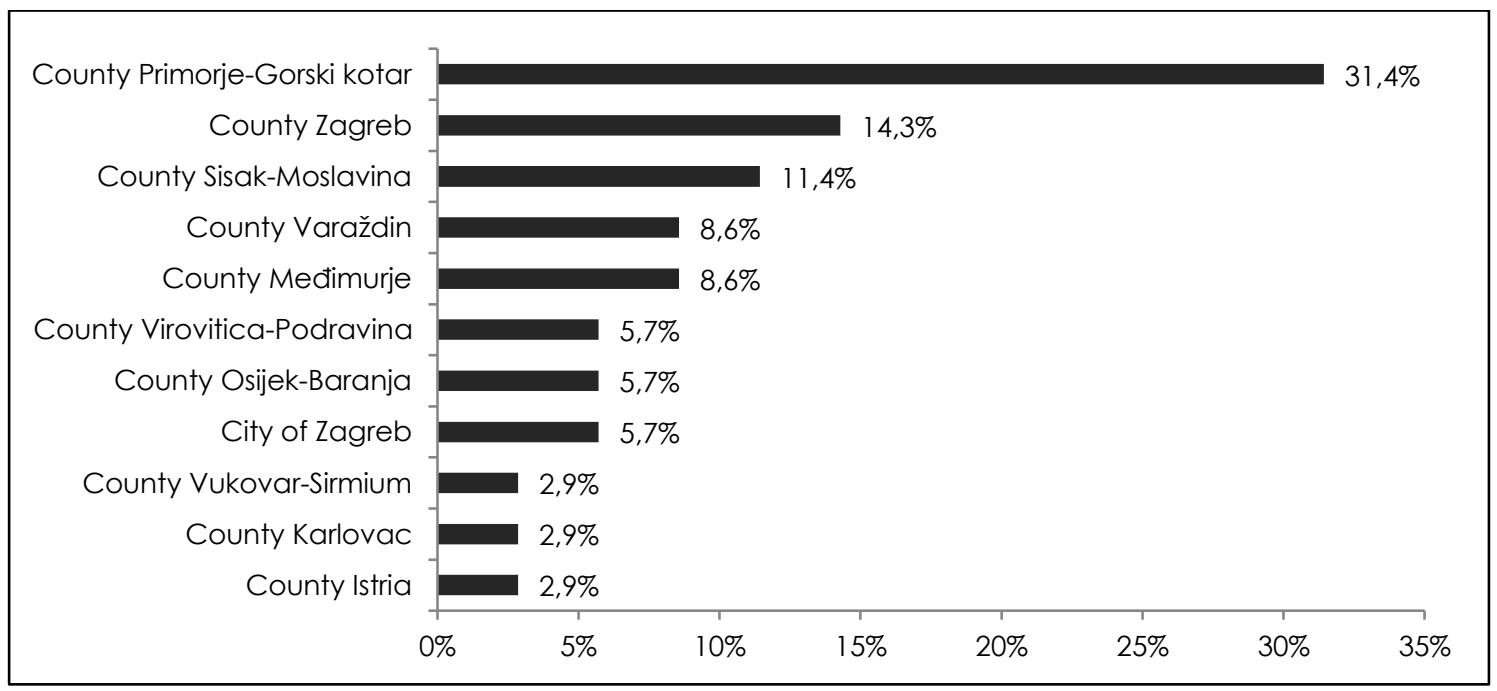

Figure 5 Respondents' profile by counties, $n=34$

Source: author's calculation. 
Table 2 Companies' profile, $n=34$

\begin{tabular}{|c|c|c|c|}
\hline & & Frequency & Percent (\%) \\
\hline \multirow{5}{*}{ Age of company (years) } & less than 10 & 6 & 17,6 \\
\hline & between 10 and 20 & 6 & 17,6 \\
\hline & between 20 and 30 & 18 & 52,9 \\
\hline & over 30 & 4 & 11,8 \\
\hline & Total & 34 & 100,0 \\
\hline \multirow{5}{*}{ Number of employees } & less than 10 & 4 & 11,8 \\
\hline & between 10 and 50 & 15 & 44,1 \\
\hline & between 50 and 250 & 13 & 38,2 \\
\hline & more than 250 & 2 & 5,9 \\
\hline & Total & 34 & 100,0 \\
\hline \multirow{4}{*}{ Revenue category } & less than $2 \mathrm{~m} €$ & 11 & 34,4 \\
\hline & between 2 and $10 \mathrm{~m} €$ & 14 & 43,8 \\
\hline & between 10 and $50 \mathrm{~m} €$ & 7 & 21,9 \\
\hline & Total & 32 & 100,0 \\
\hline \multirow{6}{*}{$\begin{array}{l}\text { Export category (share of total } \\
\text { export in total revenues, in \%) }\end{array}$} & less than $10 \%$ & 4 & 12,5 \\
\hline & between 10 and $30 \%$ & 2 & 6,3 \\
\hline & between 30 and $50 \%$ & 7 & 21,9 \\
\hline & between 50 and $70 \%$ & 3 & 9,4 \\
\hline & $70 \%$ and over & 16 & 50,0 \\
\hline & Total & 32 & 100,0 \\
\hline \multirow{4}{*}{ Market for purchasing inputs } & $\begin{array}{l}\text { Local/regional markets } \\
\text { (within Croatia) }\end{array}$ & 9 & 27,3 \\
\hline & National markets & 17 & 51,5 \\
\hline & International & 7 & 21,2 \\
\hline & Total & 33 & 100,0 \\
\hline \multirow{4}{*}{ Market for selling products } & $\begin{array}{l}\text { Local/regional markets } \\
\text { (within Croatia) }\end{array}$ & 2 & 5,9 \\
\hline & National markets & 8 & 23,5 \\
\hline & International & 24 & 70,6 \\
\hline & Total & 34 & 100,0 \\
\hline
\end{tabular}

Source: author's calculation based on survey data.

The sample profile presented in Table 2 indicates that $82.3 \%$ of the total sample was mostly small and medium-sized companies. Only 5.9\% (2 companies) of the companies participating in the research have more than 250 workers. Most of these companies $(65.7 \%)$ have been operating for over 20 years, $51.4 \%$ of the companies are between 20 and 30 years old, $14.3 \%$ are more than 30 years old. For all respondents the mean of the years in business was 24 years. The oldest respondent company was established in 1948, while the youngest one in 2014. Companies in the sample generated an average of 8 million euros of revenues annually between 2014 and 2016. 43.8\% of respondents reported that their company average annual revenues were between 2 and 10 million euros 20142016, while about $34 \%$ of the companies studied recorded average annual revenues in the amount less than 2 million euros. At the same time, about $22 \%$ of the responding companies generated a revenue volume of between 10 and 50 million euros. Additionally, regarding the export activity, only 3 (8 percent) of respondent companies were not exporters. Even 50 percent of respondents, on average, indicated that 70 percent or more of their company annual revenue was achieved on the international market.

\section{Survey results - descriptive statistics}

After the screening questions, the respondents were asked to indicate levels of agreement with the statements regarding cooperation within the cluster $11=$ disagree, 5 = agree). Although, in general, survey results indicate that the cooperation among the cluster members is satisfactory, there is a significant room for improvement. Based on Figure 6 the highest mean is 3.36 for the statement 
"this cluster readily accepts new members to its network of exchange partners in the cluster", with 48.5 percent of the total respondents agreeing and agreeing completely with the statement. The next highest mean is 3.32 for the statement: "we are connected to a range of companies, differing in size, age, capabilities, in the industry", and here an even 50.0 percent of the total respondents disagree and strongly disagree with this statement. The results also indicate that a significant number of respondents chose to be indifferent.

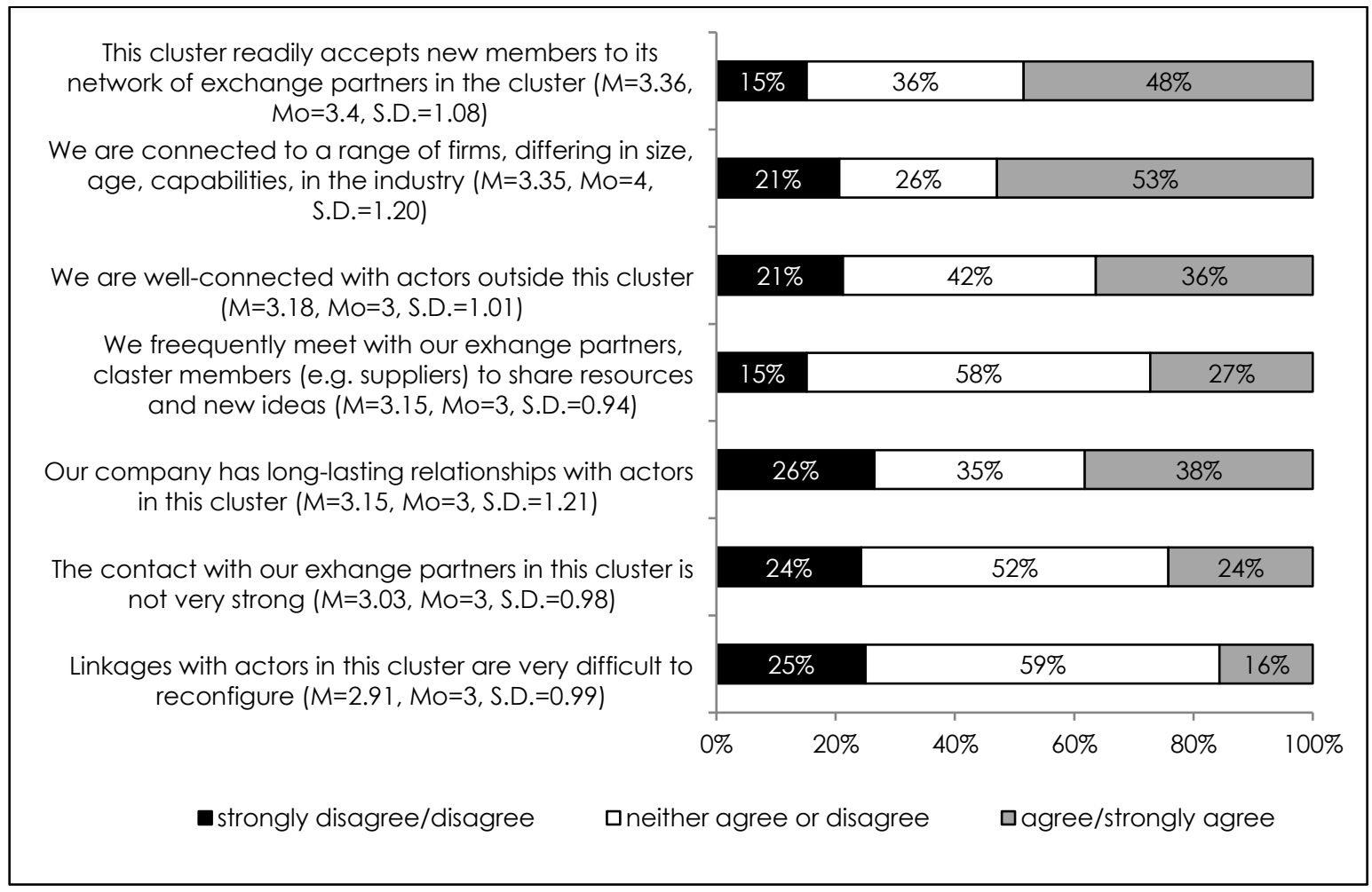

Figure 6 Strength of cooperation within the cluster, $n=34$

Source: author's calculation based on survey data.

Regarding the strength of cooperation with companies and other players outside the cluster, the strongest cooperation is indicated with the suppliers of capital equipment and with the suppliers of components (Figure 7). On the other hand, a significant number of the respondents indicated the weakest cooperation with public authorities, financial institutions and competitors.

Cluster resources and business setting in Croatia. Respondents were also asked to assess to what degree their access to the cluster resources is important for competitiveness of their company. In general, respondents saw relatively high importance for the competitiveness of their companies in areas such as the access to fairs and exhibitions, and access to institutions of technological research (i.e. universities, public institutes) as well as professional institutions related to the company core activity (i.e. associations, cooperatives and others) and the availability of skilled workers in the region (theirs and surrounding counties). However, in general, we can conclude that the respondents do not think that cluster resources have a significant influence on the competitiveness of their company. 


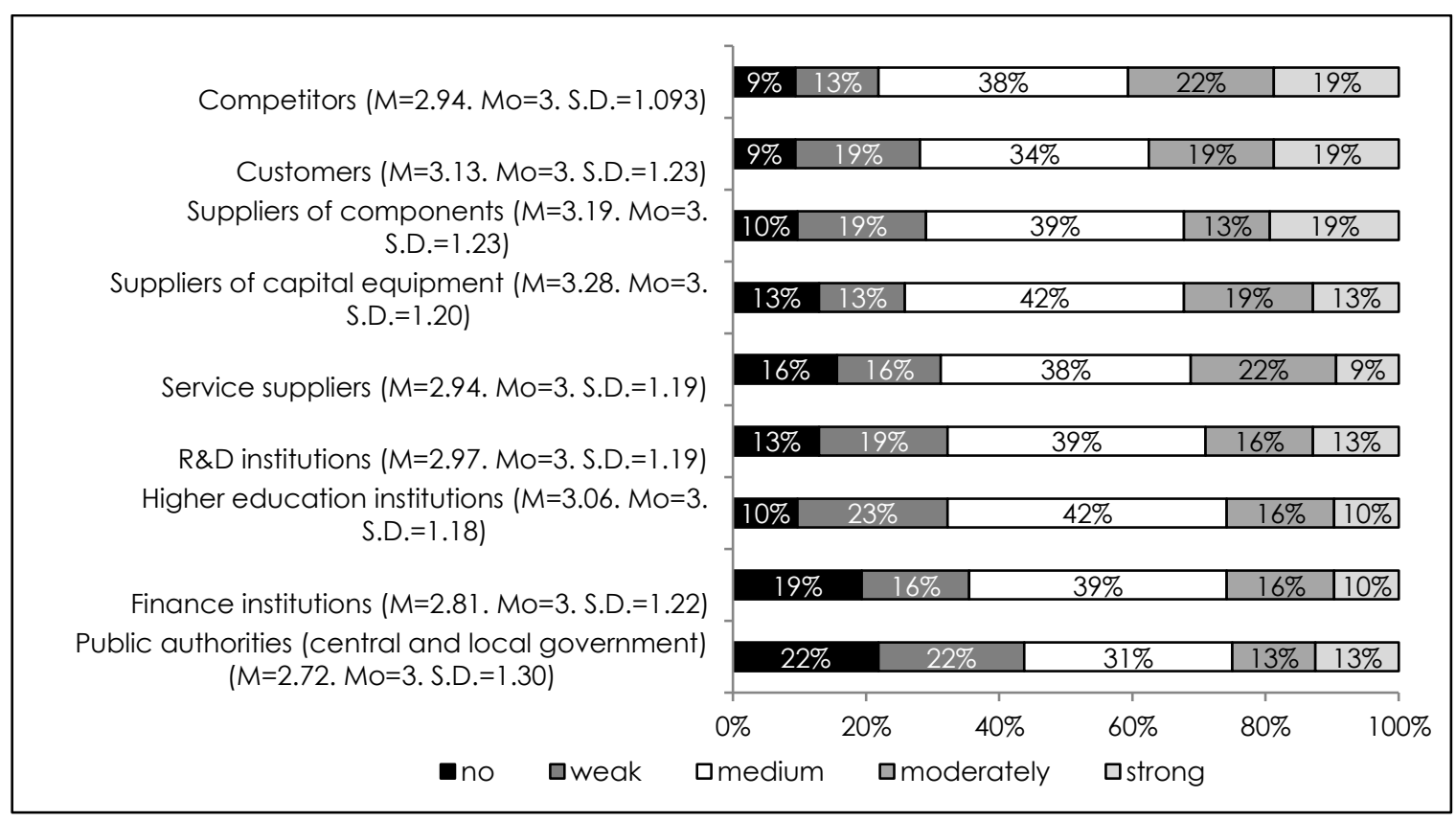

Figure 7 The strength of cooperation with companies and other players outside the cluster, $n=34$

Source: author's calculation based on survey data.

Table 3 Access to local, institutional and network cluster resources as a significant source of competitiveness, where is 1 (not at all) - 5 (completely), $n=34$

\begin{tabular}{|c|c|c|c|c|c|}
\hline & Mean & Mode & S.D. & Min & Max \\
\hline Fairs and exhibitions. & 3.18 & 3 & 1.402 & 1 & 5 \\
\hline $\begin{array}{l}\text { Institutions of technological research (i.e. universities, public } \\
\text { institutes). }\end{array}$ & 3.10 & 3 & 1.165 & 1 & 5 \\
\hline $\begin{array}{l}\text { Professional institutions related to the company's core activity (i.e. } \\
\text { associations, cooperatives and others). }\end{array}$ & 3.06 & 3 & 1.029 & 1 & 5 \\
\hline $\begin{array}{l}\text { Availability of skilled worker in the region your and surrounding } \\
\text { counties). }\end{array}$ & 2.91 & $3 \& 4$ & 1.304 & 1 & 5 \\
\hline Reputation of the region (your and surrounding counties). & 2.90 & 3 & 1.165 & 1 & 5 \\
\hline $\begin{array}{l}\text { Existence of vertical cooperation in the region (cooperation } \\
\text { networks with suppliers, distributors in the region) }\end{array}$ & 2.88 & 3 & 1.023 & 1 & 5 \\
\hline Consulting companies. & 2.88 & 2 & 1.111 & 1 & 5 \\
\hline ers in the region (your & 2.84 & 2 & 1.110 & 1 & 5 \\
\hline $\begin{array}{l}\text { Relations of horizontal cooperation between companies } \\
\text { (partnerships or companies in the sector/industry network) }\end{array}$ & 2.81 & 3 & 0.931 & 1 & 5 \\
\hline $\begin{array}{l}\text { Institutions that promote cluster governance (e.g. AlK - Croatian } \\
\text { Agency for investments and competitiveness) }\end{array}$ & 2.79 & 3 & 0.927 & 1 & 5 \\
\hline Access to credit & 2.75 & 4 & 1.270 & 1 & 5 \\
\hline $\begin{array}{l}\text { Local logistic infrastructure (distribution of products and access to } \\
\text { the suppliers) }\end{array}$ & 2.72 & 2 & 1.170 & 1 & 5 \\
\hline Access to local service. & 2.69 & 2 & 1.091 & 1 & \\
\hline Competitors in the region (your and surrounding counties) & 2.66 & 3 & 1.096 & 1 & \\
\hline
\end{tabular}

Competitors in the region (your and surrounding counties)

Source: author's calculation based on survey data.

Overall, the respondents saw weaknesses in all given aspects of the Croatian business environment. The results also show that the respondents are mostly negative to the government policy in general as well as to the industrial policy. Even 68 percent of the total respondents disagree and strongly disagree with the statement that "Government policy is stable and predictable" and 61 percent disagree with the statement that "Industrial policy focuses on reginal or local level". 


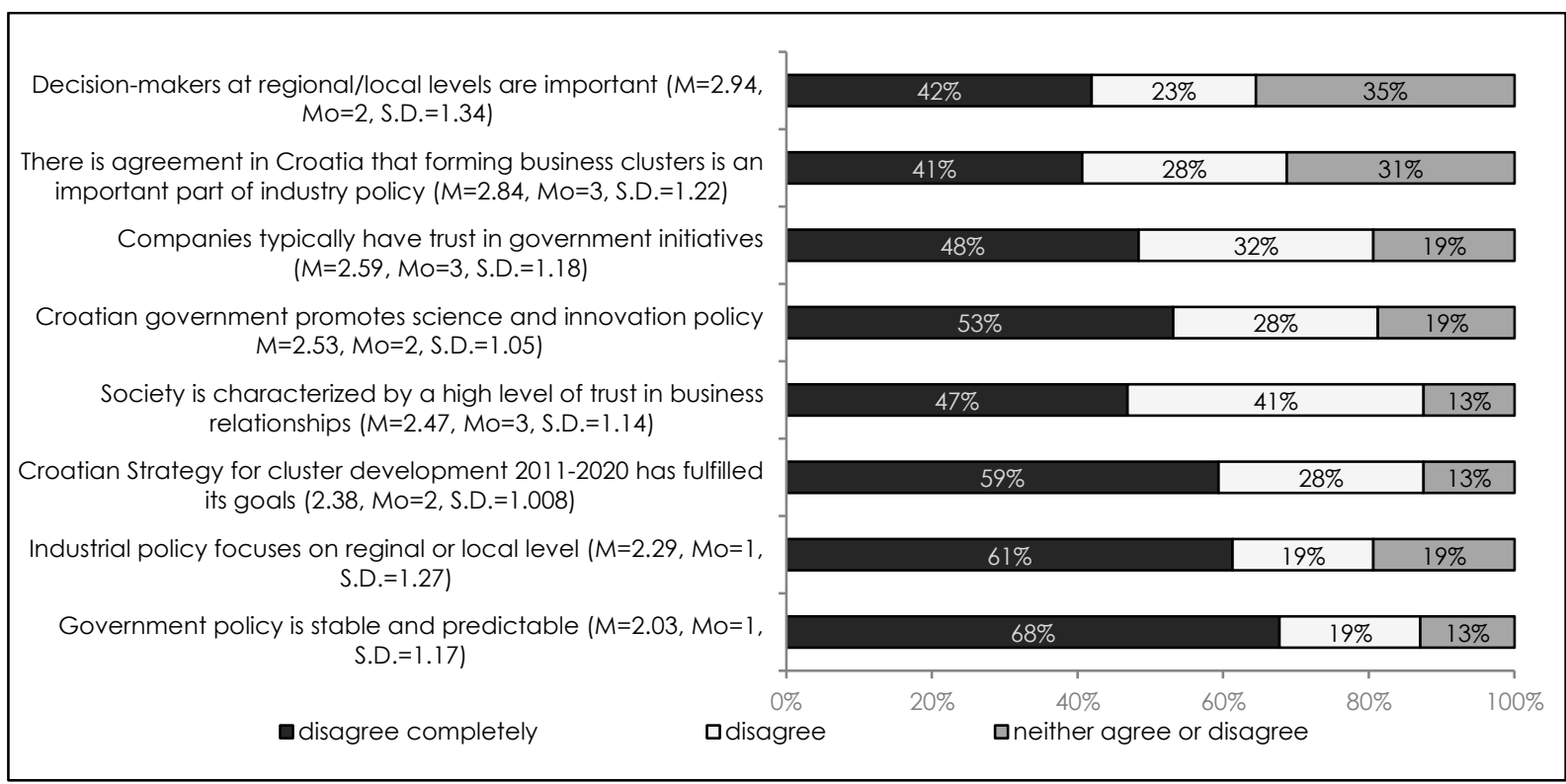

Figure 8 Croatian business environment, $n=34$

Source: author's calculation based on survey data

Cluster membership and performance of the clustered companies. In the next set of questions, the respondents were asked to assess the impact of the cluster membership on their company performance during the last three years. Companies studied in this survey in general do not think that the membership in this cluster has affected their company's performance, especially regarding employment, investment, competitiveness, revenues etc. (Table 4). The lowest mean value is 1.91 for the statement "Cluster has led to increased employment" with $72 \%$ and for the statement "Cluster has increased FDI" $78 \%$ of the total respondents disagree and strongly disagree with the statement.

Table 4 Impact of the cluster membership on the performance of the studied companies during the last 3 years, where 1 (disagree completely) - 5 (agree

completely), $\mathrm{n}=34$

Cluster has led to increased employment.

Cluster has increased FDI.

Cluster has led to closer ties with buyers on the international

market.

Cluster has promoted export of higher value added products.

Cluster has improved international competitiveness of

company.

Cluster has helped the company increase revenues.

Cluster has led to increased collaboration with International

companies within GVC.

New technologies have emerged through cluster.

Cluster has been disappointing, no changes.

The relationship among actors in cluster can be considered

highly cooperative.

Cluster has led to closer industry-academia ties.

Cluster has led to closer ties with suppliers of inputs.

Cluster has led to closer ties with other companies within the

cluster.

The cooperation with other cluster members has led to the

transfer of knowledge and skills.

Cluster has met its goals.

The cooperation with other cluster members has led to higher level of trust.

Cluster has been mostly talk, not much action.

\begin{tabular}{|r|r|r|l|r|r|}
\hline $\mathrm{N}$ & Mean & Mode & S.D. & Min & Max \\
\hline 34 & 1.91 & 1 & 0.963 & 1 & 4 \\
34 & 1.91 & 2 & 0.893 & 1 & 4 \\
34 & 2 & 1 & 0.894 & 1 & 4 \\
34 & 2.06 & 1 & 1.014 & 1 & 4 \\
34 & 2.09 & 1 & 1.118 & 1 & 4 \\
34 & 2.13 & 2 & 0.942 & 1 & 5 \\
34 & 2.16 & 1 & 1.081 & 1 & 4 \\
34 & 2.22 & 3 & 1.008 & 1 & 4 \\
34 & 2.38 & 1 & 1.212 & 1 & 5 \\
34 & 2.55 & 3 & 0.925 & 1 & 4 \\
34 & 2.59 & 2 & 1.103 & 1 & 5 \\
34 & 2.61 & 3 & 1.202 & 1 & 5 \\
34 & 2.68 & 3 & 1.013 & 1 & 5 \\
34 & 2.68 & 3 & 0.945 & 1 & 4 \\
34 & 2.78 & 3 & 1.008 & 1 & 5 \\
34 & 2.84 & 3 & 0.969 & 1 & 5 \\
34 & & 3 & 1.295 & 1 & 5 \\
\hline
\end{tabular}

Source: author's calculation based on survey data. 
In the next question the respondents indicated how much the Cluster has affected the way of doing business of their company during the last 3 years (a scale from one to five was used: 1 (disagree completely) - 5 (agree completely). Regarded by the majority of the respondents, the CWC has not affected the business of their company in given areas (Table 5). The majority of the respondents reported that they disagree or strongly disagree with the statement that the cluster has contributed to the fast restructuring of the company (65.0\%), to the decrease in the risk of diversification (68.8\%), sharing costs and resources $(62.5 \%)$, development of new products and services (62.5\%), improved access and expansion to new markets (62.5\%). However, it should be noted that a high percentage of the total respondents had no particular attitude towards the statements.

Table 5 Impacts of cluster membership on way of doing business of the company during the last 3 years, $n=34$

\begin{tabular}{|c|c|c|c|c|c|}
\hline & Mean & Mode & S.D. & Min & Max \\
\hline $\begin{array}{l}\text { Introduction of new methods of products introduction and } \\
\text { distribution channels. }\end{array}$ & 2.44 & 3 & 1.045 & 1 & 5 \\
\hline Overcoming regulatory barriers. & 2.41 & 3 & 1.043 & 1 & 4 \\
\hline Improved quality of products and services. & 2.37 & 3 & 1.066 & 1 & 4 \\
\hline Sharing skills and knowledge. & 2.34 & 3 & 0.827 & 1 & 4 \\
\hline Improved access to distribution channels and supply. & 2.31 & 3 & 1.061 & 1 & 4 \\
\hline Improved access to new technology. & 2.28 & 3 & 0.991 & 1 & 5 \\
\hline Meeting technological standards. & 2.28 & 3 & 1.023 & 1 & 5 \\
\hline Shorter time of response to clients' requirements. & 2.25 & 3 & 1.016 & 1 & 4 \\
\hline $\begin{array}{l}\text { Introduction of new methods of setting prices of goods and } \\
\text { services. }\end{array}$ & 2.25 & 3 & 0.916 & 1 & 4 \\
\hline Improved access and expansion to new markets. & 2.22 & 2 & 0.941 & 1 & 4 \\
\hline Development of new products and services. & 2.16 & 2 & 0.847 & 1 & 4 \\
\hline Sharing costs and resources. & 2.09 & 1 & 1.027 & 1 & 4 \\
\hline Decreasing the risk of diversification. & 2.00 & 2 & 0.803 & 1 & 3 \\
\hline Fast restructuring of the company. & 1.97 & 1 & 0.999 & 1 & 4 \\
\hline
\end{tabular}

Source: author's calculation based on survey data.

Threats to the development of business clusters in Croatia. Since in reality there are barriers of many kinds that influence the work of the cluster, the respondents were asked to indicate the main barriers for the work of the Croatian Wood Cluster. The most common barriers indicated by the respondents are the following: current government measures are not relevant, lack of financial resource and lack of capacity of business cluster (Table 6).

Table 6 Main barriers for the work of your cluster from 1 (factor is not a barrier) - 5 (factor is important barrier), $\mathrm{n}=34$

\begin{tabular}{|l|r|r|r|r|r|}
\hline & $\begin{array}{c}\text { not a } \\
\text { barrier }\end{array}$ & $\begin{array}{c}\text { slightly } \\
\text { barrier }\end{array}$ & $\begin{array}{r}\text { somewhat } \\
\text { of a barrier }\end{array}$ & $\begin{array}{r}\text { moderate } \\
\text { barrier }\end{array}$ & $\begin{array}{c}\text { important } \\
\text { barrier }\end{array}$ \\
\hline Lack of mutual trust among actors in the cluster. & $6.3 \%$ & $18.8 \%$ & $37.5 \%$ & $31.3 \%$ & $6.3 \%$ \\
Actors in the cluster are competitors to each other & $6.3 \%$ & $28.1 \%$ & $46.9 \%$ & $12.5 \%$ & $6.3 \%$ \\
and there is a conflict of interests. & & & & & $12.5 \%$ \\
Lack of financial resources. & $6.3 \%$ & $15.6 \%$ & $43.8 \%$ & $21.9 \%$ & $12.5 \%$ \\
Poor management. & $15.6 \%$ & $43.8 \%$ & $28.1 \%$ & $6.3 \%$ \\
Activities that are performed by cluster are not & & $21.9 \%$ & $46.9 \%$ & $12.5 \%$ & $3.1 \%$ \\
relevant. & $6.3 \%$ & $15.6 \%$ & $40.6 \%$ & $21.9 \%$ & $15.6 \%$ \\
Current government measures are not relevant. & $3.1 \%$ & $18.8 \%$ & $53.1 \%$ & $18.8 \%$ & $6.3 \%$ \\
\hline
\end{tabular}

Source: author's calculation based on survey data.

The respondents were asked to rate the importance of recommendations for public policy-makers for improving the performance of business clusters. The most 
important recommendations are: stimulating the development of new innovative products; improvement of regulatory policies; application of advanced technologies (KET) in the sector and lobbying by the Croatian government for the development of infrastructure and related institutions (Table 7).

Table 7 Recommendations for public policy-makers for improving the performance of business clusters, $n=34$

\begin{tabular}{|c|c|c|c|c|c|}
\hline & Mean & Mode & S.D. & Min & Max \\
\hline Stimulating the development of new innovative products. & 4.1 & $4 \& 5$ & 0.93 & 1 & 5 \\
\hline Improvement of regulatory policies. & 4.0 & 4 & 1.05 & 1 & 5 \\
\hline Application of advanced technologies (KET) in the sector. & 3.9 & $4 \& 5$ & 1.01 & 1 & 5 \\
\hline $\begin{array}{l}\text { Lobbying by the Croatian government for the development of } \\
\text { infrastructure and related institutions. }\end{array}$ & 3.9 & 4 & 0.89 & 1 & 5 \\
\hline $\begin{array}{l}\text { Stimulation of modernization of factories through robotization, } \\
\text { automatization, and inclusion of innovative communication } \\
\text { technologies (3D printers) and sophisticated electronic components } \\
\text { in the production processes of the sector. }\end{array}$ & 3.8 & 4 & 0.98 & 1 & 5 \\
\hline $\begin{array}{l}\text { Enhance and enable transfer of best practices from European } \\
\text { clusters to overcome the lack of experience in running cluster } \\
\text { programmes and improve efficiency in cluster governance. }\end{array}$ & 3.8 & 5 & 1.17 & 1 & 5 \\
\hline Inclusion in the international global value chains. & 3.8 & 4 & 0.96 & 1 & 5 \\
\hline $\begin{array}{l}\text { Stimulating cooperation among public, private sector and academic } \\
\text { community through both business clusters and clusters of } \\
\text { competitiveness. }\end{array}$ & 3.8 & 4 & 1.05 & 1 & 5 \\
\hline $\begin{array}{l}\text { Speed up the actions within SMART policy to support the } \\
\text { development of new products and services through R\&D (IRI) }\end{array}$ & 3.7 & 4 & 1.00 & 1 & 5 \\
\hline $\begin{array}{l}\text { Support to the development of education programs within Centres of } \\
\text { competence that stimulate lifelong learning. }\end{array}$ & 3.6 & 3 & 1.04 & 1 & 5 \\
\hline Speed up the programme of Centres of Competence (CEKOM) & 3.5 & 4 & 0.94 & 1 & 5 \\
\hline
\end{tabular}

Source: author's calculation based on survey data.

As far as the relevance of government policies for cluster development is concerned, the companies studied in this research think that the most important government policies are: financial support to individual companies' projects, providing information on different fields, support of infrastructure (both physical and know-how infrastructure), providing information on export market, support to research programs (Table 8 ).

Table 8 Relevance of government policies for cluster development, $n=34$

\begin{tabular}{|l|r|r|r|r|r|}
\hline & Mean & Mode & \multicolumn{1}{c|}{ S.D. } & Min & Max \\
\hline Financial support of companies' projects. & 4.25 & 5 & 0.984 & 1 & 5 \\
Provide information on general business fields. & 4.06 & 5 & 1.059 & 1 & 5 \\
Investment in knowledge infrastructure (such as education & 4.03 & 5 & 1.015 & 1 & 5 \\
institutions). & & & & \\
Provide information on export market. & 4 & & 1.146 & 1 & 5 \\
Support to education and training programs. & 4 & 4 & 1.031 & 1 & 5 \\
Support to research projects/programs. & 3.97 & 4 & 0.951 & 1 & 5 \\
Advice and consulting for individual companies. & 3.85 & 4 & 1.093 & 1 & 5 \\
Provide information on technological fields. & 3.85 & 4 & 1.149 & 1 & 5 \\
Policies to attract outside companies to the cluster. & 3.64 & 4 & 0.929 & 1 & 5 \\
Support to physical infrastructure. & 3.64 & 4 & 0.895 & 1 & 5 \\
Support to networking and collaboration. & 3.61 & 4 & 0.933 & 1 & 5 \\
Support to mobility schemes. & 3.55 & 4 & 0.833 & 1 & 5 \\
Foster social interaction. & 3 & 0.906 & 1 & 5 \\
\hline
\end{tabular}

Source: author's calculation based on survey data.

\section{The impact of clustering on firm performance - factor analysis and regression analysis}

The main objective of this part of the analysis it to find out what aspects of networking/cooperation provided by the Croatian Wood Cluster are associated with the business performance of the clustered companies. Therefore, in the first 
step two separate factor analyses were conducted. The first factor analysis was used to identify key dimensions of cooperation, networking and resources of the Croatian Wood Cluster, while the second one was used to identify key dimensions of the performance of a company which is a member of the cluster, of the performance of the cluster and of the impact of the cluster on performance of the clustered companies. Since there are no assumptions about the number of factors, explorative factor analysis was used. The factors are obtained as independent linear combinations of correlated input variables. In the first step of the analysis it was examined how justified it is to use factor analysis, and the most appropriate method of the factor analysis was selected. The precondition for factor analysis to be suitable is that the Bartlett's Test of Sphericity should be significant $(p<0.05)$ (Hair, Tatham, Anderson, 2010). Since factor analysis results are used as input variables for regression (Morrison, 1987), the principal component analysis (PCA) was used. Namely, the basic advantage of the PCA is that it allows for the direct identification of the factor scores. For comparison, in the common factor analysis factor scores are estimated. In cases when obtained factor scores are used as input variables for further analyses, the theory recommends varimax orthogonal rotation (Johnson, Wichern, 1992). In an orthogonal solution, the factor axes are maintained at 90 degrees meaning that factors are mutually independent. For solving the number of factors, the Kaiser's eigenvalve-greaterthan-one rule criterion was used.

\section{Factor analysis}

Five items were used as input variables for measuring the strength of cooperation and networking within the cluster, six items, which measure the cooperation with the players outside the cluster, and nine items, which measure the importance of access to cluster resources for the cluster members. After justification of the use of analysis, principal component analysis with varimax orthogonal rotation was conducted (Table 9).

Table 9 Input variables for first Factor analysis

\begin{tabular}{|c|c|}
\hline Code & Description of the variable \\
\hline ClusterCooperl & Our company has long-lasting relationships with actors in this cluster \\
\hline ClusterCooper2 & We frequently meet with our exchange partners \\
\hline ClusterCooper3 & $\begin{array}{l}\text { We are connected to a range of companies, differing in size, age, capabilities, in the } \\
\text { industry }\end{array}$ \\
\hline ClusterCooper4 & The contact with our exchange partners in this cluster is not very strong. \\
\hline ClusterCooper5 & This cluster readily accepts new members to its network of exchange partners in the cluster \\
\hline ExternalCooper 1 & Strength of cooperation with public authorities \\
\hline ExternalCooper2 & Strength of cooperation with finance institutions \\
\hline ExternalCooper3 & Strength of cooperation with higher education institutions \\
\hline ExternalCooper4 & Strength of cooperation with R\&D institutions \\
\hline ExternalCooper5 & Strength of cooperation with service suppliers \\
\hline ExternalCooper7 & Strength of cooperation with suppliers of components \\
\hline Resourcess 1 & Access to institutions of technological research \\
\hline Resourcess2 & Access to professional institutions related to core activity of company \\
\hline Resourcess3 & Access to institutions that promote cluster governance \\
\hline Resourcess6 & Access to credit \\
\hline Resourcess7 & Availability of skilled worker in the region \\
\hline Resourcess8 & Reputation of the region \\
\hline Resourcess9 & Relations of horizontal cooperation between companies \\
\hline Resourcess 11 & Customers in the region \\
\hline Resourcess 12 & Competitors in the region \\
\hline Resourcess 14 & Fairs and exhibitions \\
\hline
\end{tabular}

Source: author's systematization based on survey data. 
The factor analysis results are presented in a form of a factor matrix. Each factor is represented by column of the matrix. Each column contains factor loadings for each variable on each factor. Factor loading is the correlation between the original variable and the factor. Table 10 presents a rotated factor solution. This solution is obtained using principal component analysis with varimax rotation. Four factors that meet eigenvalue criterion are obtained, accounting for 79.6 percent of the total variance. First factor accounts for $25.9 \%$, second for $24.4 \%$, third for $16.9 \%$ and forth for $12.4 \%$. The lowest acceptable level of the percentage of variance explained in social sciences is $60 \%$ (Hair, Tahtam, Anderson, 2010). Since the first factor has positive high factor loadings on the variables: "Strength of cooperation with public authorities", "Strength of cooperation with finance institutions", "Access to local services" and "Reputation of the region", "Access to institutions that promote cluster governance" (e.g. AIK Croatian Agency for investments and competitiveness), "Relations of horizontal cooperation between companies (the existence of partnerships or companies in the sector/industry network)" and "Access to fairs and exhibitions" it is labelled as "Cooperation with other institutions (public, finance, AIK)", "Access to fairs and to relations of horizontal cooperation between companies (the existence of partnerships or companies in the sector/industry network)". The second factor has high positive loading on the variable "This cluster readily accepts new members to its network of exchange partners in the cluster", "Strength of cooperation with higher education institutions", "Strength of cooperation with R\&D institutions", "Access to institutions of technological research (i.e. universities, public institutes)" and "Access to professional institutions related to core activity of company (i.e. associations, cooperatives and others)". This factor was named "Strong cooperation with scientific, high education and research institutions, openness of the cluster". The third factor is named "Access to credit, access to customers and competitors". The fourth factor labelled "Strong cooperation within the cluster" has high positive loadings on the variables "Long-lasting relationships with actors in this cluster", "Frequent cooperation with exchange partners", "Established connections to a range of companies, differing in size, age, capabilities, in the industry".

Table 10 Varimax rotated factor matrix

\begin{tabular}{|l|c|c|c|c|}
\hline & F1 & F2 & F3 & F4 \\
\hline ClusterCooper1 & 0.27 & 0.01 & 0.10 & 0.82 \\
ClusterCooper2 & 0.31 & 0.29 & 0.19 & 0.80 \\
ClusterCooper3 & -0.12 & 0.12 & 0.10 & 0.73 \\
ClusterCooper4 & -0.05 & 0.35 & 0.45 & 0.38 \\
ClusterCooper5 & 0.28 & 0.80 & 0.27 & 0.18 \\
ExternalCooper1 & 0.72 & 0.19 & 0.26 & 0.37 \\
ExternalCooper2 & 0.82 & 0.25 & 0.29 & 0.18 \\
ExternalCooper3 & 0.33 & 0.82 & 0.27 & 0.03 \\
ExternalCooper4 & 0.40 & 0.80 & 0.10 & 0.10 \\
ExternalCooper5 & 0.76 & 0.45 & 0.19 & 0.19 \\
ExternalCooper7 & 0.61 & 0.55 & 0.10 & 0.26 \\
Resourcess1 & 0.33 & 0.74 & 0.19 & 0.26 \\
Resourcess2 & 0.56 & 0.67 & 0.24 & 0.10 \\
Resourcess3 & 0.60 & 0.50 & 0.44 & 0.04 \\
Resourcess6 & 0.30 & 0.05 & 0.81 & 0.13 \\
Resourcess8 & 0.63 & 0.44 & 0.45 & 0.09 \\
Resourcess9 & 0.59 & 0.39 & 0.48 & -0.02 \\
Resourcess11 & 0.33 & 0.40 & 0.74 & 0.09 \\
Resourcess12 & 0.24 & 0.24 & 0.85 & 0.23 \\
Resourcess14 & 0.84 & 0.33 & 0.18 & -0.06 \\
\hline
\end{tabular}

Source: author's calculation. 
The second factor analysis was used to identify key dimensions of performance of the companies, which are members of the cluster, of performance of the cluster and of the impact of the cluster on the performance of the clustered companies. Six items were used as input variables which measure the impact of cluster specific conditions on the clustered company performance, seven variables which measure the performance of the cluster itself, two items measuring the effectiveness of the work of the cluster, and thirteen items were used which measure the impacts of cluster membership on way of doing business of the companies studied (Table 11).

Table 11 Input variables for the second factor analysis

\begin{tabular}{|l|l|}
\hline \multicolumn{1}{|c|}{ Code } & \multicolumn{1}{c|}{ Description of the variable } \\
\hline RESULT1 & Cluster has helped the company increase revenues. \\
RESULT2 & Cluster has led to increased employment. \\
RESULT3 & Cluster has promoted export of higher value added products. \\
INTERNATRESU1 & Cluster has improved international competitiveness of company. \\
INTERNATRESU2 & Cluster has led to increased collaboration with International companies within GVCs \\
INTERNATRESU3 & Cluster has increased FDI. \\
CLUSTERSUCCESS1 & Cluster has led to closer industry-academia ties. \\
CLUSTERSUCCESS2 & The relationship among actors in cluster can be considered highly cooperative. \\
CLUSTERSUCCESS3 & Cluster has led to closer ties with other companies within the cluster. \\
CLUSTERSUCCESS4 & The cooperation with other cluster members has led to higher level of trust. \\
CLUSTERSUCCESS5 & The cooperation with other cluster members has led to the transfer of knowledge and \\
CLUSTERSUCCESS6 & skills. \\
CLUSTERSUCCESS7 & New technologies have emerged through cluster. \\
CLUSTERSUCCESS8 & Cluster has met its goals. \\
CLUSTERSUCCESS9 & Cluster has been disappointing, no changes. \\
CLUSTERSUCCESS10 & Sharing skills and knowledge. \\
BUSINESS1 & Fast restructuring of the company. \\
BUSINESS2 & Improved access to distribution channels and supply. \\
BUSINESS3 & Improved access to new technology. \\
BUSINESS4 & Development of new products and services. \\
BUSINESS5 & Sharing costs and resources. \\
BUSINESS6 & Decreasing the risk of diversification. \\
BUSINESS7 & Meeting technological standards. \\
BUSINESS8 & Overcoming regulatory barriers. \\
BUSINESS9 & Improved quality of products and services. \\
BUSINESS10 & Shorter time of response to clients' requirements. \\
BUSINESS11 & Introduction of new methods of products introduction and distribution channels. \\
BUSINESS12 & Introduction of new methods of setting prices of goods and services. \\
BUSINESS13 & Improved access and expansion to new markets. \\
\hline SOUICE: aUthOr'S Systematization based on survey data.
\end{tabular}

Source: author's systematization based on survey data.

After justification of the use of analysis, principal component analysis with varimax orthogonal rotation was conducted. As a result, four dimensions were extracted. The first dimension accounts for $25.9 \%$ of the total variance and has high positive loadings on the variables related to the positive impact of the cluster membership on the way of doing business of the clustered companies. Therefore, this dimension is labelled as "Improved way of doing business of the companies". Since the second dimension has high positive loadings on the variables related to operational and finance based performance of the companies, it is named "Improved finance-based performance of the companies" and it accounts for 19.4 percent of the total variance. The third extracted dimension has high positive loadings on the variables measuring successful performance of the cluster, is labelled "Cluster performance", and accounts for 18.4 percent of total variance. The fourth is named "Ineffectiveness of the CWC" $(6.4 \%)$ as it has high positive loadings on the variable measuring ineffectiveness of the cluster ("disappointment with the cluster activity"). The fifth dimension is labelled "Sharing 
skills and knowledge" since it has high and positive factor loadings on the variable "Sharing skills and knowledge" and accounts for $5.8 \%$ of total variance.

\section{Regression analysis}

According to cluster theory, the cluster networking and cooperation (relations of competition, collaboration, and cooperation) have positive impact on productivity, innovation and economic performance of the clustered companies (Devereux, Griffith, Simpson 2007, Ellison, Glaeser, Kerr, 2010). Therefore, it is interesting to identify the factors that affect the economic performance of the connected companies (Kim, Oh, 2004).

The multiple regression analysis was used to examine the relationship between cooperation and networking provided by the cluster and the performance of the clustered companies. There are several independent variables in multiple regressions on one side of the equation and one dependent variable on the other side. The combination of variables can be considered a dimension among several variables that predicts the dependent variable. For each value of the independent variable $x$, a value of dependant variable $y$ is associated. We choose to see a model where the business success of the companies studied plays a role of the dependent variable. The independent variables are those for which we performed first factor analysis (Cooperation with public, financial institutions and AIK, access to horizontal cooperation, access to fairs $(X 1)$; Cooperation with scientific, high education and research institutions (X2); Access to credit, access to customers and competitors (X3) and Cooperation within the cluster (X4):

$$
Y_{i}=\beta_{0}+\beta_{1} X_{i 1}+\beta_{2} X_{i 2}+\beta_{3} X_{i 3}+\beta_{4} X_{i 4}+\varepsilon_{i}, i=1,2, \ldots, n
$$

Table 12 Summary of regression results, dependent variable Business success (finance-based performance) of the companies members of the Croatian Wood Cluster

\begin{tabular}{|c|c|c|c|c|c|c|}
\hline \multicolumn{7}{|l|}{$\begin{array}{l}\text { Number of obs. }=34 \\
F(4,29)=3.93 \\
\text { Prob }>F=0.0114 \\
\text { R-squared }=0.3515 \\
\text { Adj R-squared }=0.2620\end{array}$} \\
\hline Variable & Coeff. & Std. Err. & $t$ & $p$-value & $95 \%$ & \\
\hline $\begin{array}{l}\text { Cooperation with public, financial } \\
\text { institutions and AlK, access to horizontal } \\
\text { cooperation, access to fairs }\end{array}$ & 0.434 & 0.150 & 2.90 & $0.007^{*}$ & 0.128 & 0.739 \\
\hline $\begin{array}{l}\text { Cooperation with scientific, high } \\
\text { education and research institutions }\end{array}$ & 0.137 & 0.150 & 0.91 & 0.369 & -0.169 & 0.442 \\
\hline $\begin{array}{l}\text { Access to credit, access to customers } \\
\text { and competitors }\end{array}$ & 0.370 & 0.150 & 2.47 & $0.019 * *$ & 0.064 & 0.676 \\
\hline Cooperation within the cluster & 0.090 & 0.150 & 0.60 & 0.554 & -0.216 & 0.395 \\
\hline Constant & 0.000 & 0.147 & 0 & 1 & -0.301 & 0.301 \\
\hline
\end{tabular}

Note: *significant at the 0.01 level, ** significant at the 0.05 level.

Source: author's calculation.

As hypothesized, regression results provided evidence that cooperation of the cluster with public (especially with the AIK) and financial institutions, as well as access to cluster resources (such as horizontal cooperation and fairs) are positively and significantly associated with finance-based performance of the clustered companies, supporting $\mathrm{Hl}$. Also, as can be observed in Table 12 the access to cluster resources such as credit, customers and competitors has a significant positive effect on finance-based performance of the clustered 
companies, confirming the third research hypothesis $(\mathrm{H} 3)$. On the other hand, hypothesis $\mathrm{H} 2$ and $\mathrm{H} 3$ for directionally are hypothesised, but they are not found to be statistically significant. The reported results shows that cooperation among cluster members and cooperation with scientific, high education and research institutions have positive, but no significant relationship with the clustered companies finance-based performance. Therefore, $\mathrm{H} 2$ and $\mathrm{H} 4$ are not supported.

\section{Conclusions}

This paper shows the impact of cluster membership on the performance of the clustered companies on the example of the Croatian Wood Cluster. While most previous studies indicates the potential positive effects of cluster networking, the results of the conducted research suggest that clustering is generally not perceived as significantly important for the performance of the companies included in the study. It can be concluded that the respondents do not think that cluster resources have a significant influence on the competitiveness of their company, they also see a relatively higher importance for the competitiveness of their companies in areas such as the access to fairs and exhibitions, and access to the institutions for technological research (i.e. universities, public institutes), professional institutions related to the company's core activity (i.e. associations, cooperatives and others) and availability of skilled worker in the region (surrounding counties). Cluster members mostly do not think that the membership in this cluster has affected the performance of their company in the recent period, especially regarding employment, investment, competitiveness, revenues etc. These results have interesting implications for policy makers and cluster management. This will let both policy makers and managers of business cluster make decisions that enhance the performance of business clusters and the clustered companies.

Namely, the respondents saw weaknesses in all given aspects of the Croatian business environment, most negative attitude are recorded towards the government policy in general as well as to the industrial policy. Additionally, as the most common barriers to the development of the Croatian Wood Cluster respondents recognised current government measures, lack of financial resources and lack of capacity of the cluster. According to survey results, in order to improve the performance of business cluster, public policy makers should stimulate the development of new innovative products and improvement of regulatory policies; stimulation of the application of advanced technologies (KET) in the sector and lobby by the Croatian government for the development of infrastructure and related institutions. Results of the research also suggest that the most important government policies are found in four areas: financial support to individual companies' projects, provide information on different fields, support of infrastructure (both physical and knowledge infrastructure), provide information on export market, support to research programmes. These results open a deep line of study. Previous researches have shown that although Croatia has developed institutional network for cluster policy which is in compliance with the EU standards in this area, implementation of cluster policy as well as the coherence and coordination of all competent authorities and stakeholders is questionable (Dragičević, Obadić, 2013). According to Dragičević and Obadić (2013) as a prerequisite for the development of clusters, cluster mapping has to be carried out and. It is necessary to identify the location for the development of industrial clusters and thus to identify local and regional competitive advantages (Dragičević, Obadić, 2013). 
Finally, the survey results were used to examine the relationship between cooperation and networking provided by the cluster and performance of the clustered companies. Conducted regression suggest that business success of the clustered companies is significantly predicted by cooperation with public institutions, financial institutions and professional institutions such as the Agency for Investments and Competitiveness; access to cluster resources such as horizontal cooperation, fairs, exhibitions and access to credit, customers and competitors provided by the CWC. It can be concluded that for small and developing businesses, these aspects of the membership in a cluster may aid the firm in a faster growth, recognition, and status within the market.

However, this research has several methodological limitations that should be underlined and noted to point to lines for future research. The study is conducted in a specific sector and the research was conducted by using cross-sectional sample design at one given time point. Therefore, obtained results are just indicative and might not be e generalizable for all industries in Croatia. Since the results are based on survey conducted on the sample of the clustered companies, in order to obtain stronger conclusions, the economic performance of the clustered companies might be compared with performance of the companies outside the clusters. On this basis, future research could follow directions: (1) expansion of the scope of the research so that includes other important industrial clusters in Croatia (2) application of the longitudinal sample design in order to examine the causalities (3) conducting dynamic comparison of the operational performance between clustered and non-clustered companies in Croatia.

\section{References:}

1. Altenburg, T., Meyer-Stamer, J. (1999). How to Promote Clusters: Policy Experiences from Latin America. World Development, Vol. 27, No. 9, pp. 1693-1713.

2. Arrow, K. J. (1962). The economic implications of learning by doing. Review of Economic Studies, Vol. 29, No. 3, pp. 155-172.

3. Baptista, R., Swann, G. M. P. (1998). Do firms in clusters innovate more?. Research Policy, Vol. 27, No. 5, pp. 525-540.

4. Bertolini, P., Giovannetti, E. (2006). Industrial districts and internationalization: the case of the agrifood industry in Modena, Italy. Entrepreneurship \& Regional Development, Vol. 18, No. 4, pp. 279-304.

5. Chiu, Y. T. (2009). How network competence and network location influence innovation performance. Journal of Business \& Industrial Marketing, Vol. 24, No. 1, pp. 46-55.

6. Croatian Bureau of Statistics (2016). First release 4.2.1/12. Available at https://www.dzs.hr/Hrv_Eng/publication/2016/04-02-01_12_2016.htm [26 August 2017].

7. Croatian Chamber of Economy (2016). O Zajednici klastera. Available at https://www.hgk.hr/s-industriju-i-it/o-zajednici-klastera [26 August 2017].

8. Cronbach, L. J. (1951). Coefficient alpha and the internal structure of tests. Psychometrika, Vol. 16, No. 3, pp. 297-334.

9. Crouch, C., Farrell, H. (2001). Great Britain: Falling through the Holes in the Network Concept?. In Local Production Systems in Europe: Rise or Demise?, Crouch C., Le Galès P., Trigilia C., Voelzkow H. (Eds.), Oxford University Press, Oxford, pp. 154-211.

10. Devereux, M. P., Griffith, R., Simpson, H. (2007). Firm location decisions, regional grants and agglomeration externalities. Journal of Public Economics, Vol. 91, No. 3, pp. 413435.

11. Dragičević, M., Obadić, A. (2013). Klasteri i politike razvoja klastera. Ekonomski fakultet, Zagreb. 
12. Ellison, G., Glaeser, E., Kerr, W. (2010). What Causes Industry Agglomeration? Evidence from Co-agglomeration Patterns. American Economic Review, Vol. 100, No. 3, pp. $1195-1213$.

13. Eurostat (2014). Structural business statistics. Available at http://ec.europa.eu/eurostat/web/structural-business-statistics/data/main-tables [23 August 2017].

14. Fujita, M., Thisse, J. F. (2002). Economics of Agglomeration: Cities, Industrial Location, and Regional Growth. Cambridge University Press, Cambridge.

15. Giuliani, E. (2005). Cluster absorptive capacity: Why do some clusters forge ahead and others lag behind. European Urban and Regional Studies, Vol. 12, No. 3, pp. 269288.

16. Giuliani, E., Ravelotti, R., Pietrobello, C. (2005). Upgrading in Global Value Chains: Lessons from Latin American Clusters. World Development, Vol. 33, No. 4, pp. 549-573.

17. Hair, J. F., Tatham, R. L., Anderson, R. (2010). Multivariate data analysis. Person Prentice Hall.

18. Hendry, C., Brown, J. (2006). Dynamics of clustering and performance in the UK optoelectronics. Regional studies, Vol. 40, No. 7, pp. 707-725.

19. Hervas-Oliver, L. J., Albors-Garrigos, J. (2007). Do clusters capabilities matter; an empirical application of the resource based view in clusters. Entrepreneurship \& Regional Development, Vol. 19, No. 2, pp. 113-136.

20. Hrvatske šume (2017). Šume u Hrvatskoj. Available at http://portal.hrsume.hr/index.php/hr/ume/opcenito/sumeuhrv [20 September 2017].

21. Hrvatski drvni klaster (2014). Godišnje izvješće za 2013. godinu. Hrvatski drvni klaster, Zagreb.

22. Isard, W. (1956). Location and Space-Economy. A General Theory Relating to Industrial Location, Market Areas, Land Use, Trade, and Urban Structure. The Technology Press of Massachusetts Institute of Technology and John Wiley \& Sons, New York.

23. Johnson, A. R., Wichern W. D. (1992) Applied Multivariate Stastical Analysis. Prentice Hall, Upper Saddle River, New York.

24. Kersan Škabić, I. (2014). Hrvatska drvna industrija - klasteri, konkurentnost i perspektive razvoja u okviru članstva u Europskoj Uniji. Poslovna izvrsnost, Vol. 8, No. 2, pp. 57-76.

25. Kersan-Škabić, I. Afrić Rakitovac, K. (Eds.) (2011) Klasteri i gospodarski potencijali Istarske županije, Sveučilište Jurja Dobrile u Puli, Odjel za ekonomiju i turizam "Dr. Mijo Mirković", Pula.

26. Kesidou, E., Szirmai, A. (2012). External Knowledge and Innovation Performance in Clusters: Empirical Evidence from the Uruguay Software Cluster. Industry and Innovation, Vol. 19, No. 5, pp. 437-457.

27. Kim, B. Y., Oh, H. (2004). How do hotel firms obtain a competitive advantage? International Journal of Contemporary Hospitality Management, Vol. 16, No. 1, pp. 6571.

28. Krugman, P. R. (1991). Geography and Trade. MIT Press, Cambridge.

29. Lundvall, B. A., Johnson, B. (1994). The learning economy. Journal of Industry Studies, Vol. 1, No. 2, pp. 23-42.

30. Marshall, A. (1890). Principles of economics. Macmillan, London.

31. Marshall, A. (1920). Principles of Economics. Macmillan, London.

32. Morosini, P. (2004). Industrial Clusters, Knowledge Integration and Performance. World Development, Vol. 32, No. 2, pp. 305-326.

33. Morrison, A., Rabellotti, R., Zirulka, L. (2013). When do global pipelines enhance the diffusion of knowledge in clusters?. Economic Geography, Vol. 89, No. 1, pp. 77-96.

34. Morrison, F. D. (1987). Multivariate Statistical Methods. McGraw-Hill Book Co, New York.

35. Muscio, A. (2006). Patterns of Innovation in Industrial Districts: An Empirical Analysis. Industry \& Innovation, Vol. 13, No. 3, pp. 291-312.

36. OECD (1999). Boosting innovation. The cluster approach. OECD, Paris.

37. Perroux, F. (1950). Economic space: theory and applications. Quarterly Journal of Economics, Vol. 64, No. 1, pp. 90-97. 
38. Porter, M. E. (1998a). Clusters and the new economics of competition. Harvard Business Review, Vol. 76, No. 6, pp. 77-90.

39. Porter, M. E. (1998b). Location, Clusters, and the 'New' Micro Economics of competition. Business Economics, Vol. 33, No. 1, pp. 7-13.

40. Pyke, F., Sengenberger, W. (Eds.) (1992). Industrial districts and local economic regeneration. International Institute of Labor Studies, Geneva.

41. Romer, P. M. (1986). Increasing returns and long-run growth. Journal of Political Economy, Vol. 94, No. 5, pp. 1002-1037.

42. Simmie, J., Sennett, J. (1999). Innovative clusters: global or local linkages? National Institute Economic Review, Vol. 170, No. 1, pp. 70-81.

\section{About the author}

Ivana Rašić Bakarić Ph.D. works as Senior Research Associate at the Institute of Economics Zagreb, in the Department for Regional Development. She graduated at the Faculty of Economics and Business, the University of Zagreb in 2000, at the same Faculty she received her master's degree in 2005 and the PhD in 2010. Ivana Rašić Bakarić has been involved in research activities related to scientific articles publication and has collaborated with the public and business sector since 2001. She has been engaged as an expert on several projects for international organisations (European Commission, UNDP, GIZ). In 2015 she was awarded a grant from Global Development Network - Regional Research Competition 15 along with two colleagues for a research of City specialisation and factor productivity in South-East Europe. From 2008 to 2012 she had been teaching Statistics at graduate level at Faculty of Economics and Business University of Zagreb. She has published more than 20 scientific papers and has worked on eight books and even more scientific projects. She can be contacted at irasic@eizg.hr. 